\title{
Journalists' vision of the evolution of the (metaphorical) ecosystem of communication on health and biomedicine
}

\author{
Gema Revuelta-De-la-Poza
}

Nota: Este artículo se puede leer en español en:

http://www.elprofesionaldelainformacion.com/contenidos/2019/may/revuelta_es.pdf

How to cite this article:

Revuelta-De-la-Poza, Gema (2019). "Journalists' vision of the evolution of the (metaphorical) ecosystem of communication on health and biomedicine". El profesional de la información, v. 28, n. 3, e280310.

https://doi.org/10.3145/epi.2019.may.10

Manuscript received on November, 11th 2018 Accepted on January, 01st 2019

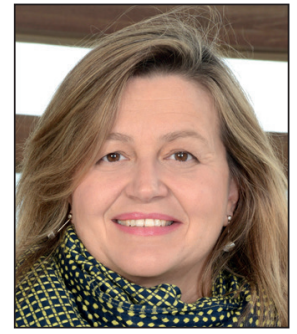

Gema Revuelta-De-la-Poza $\bowtie$

https://orcid.org/0000-0002-0701-2026

Universitat Pompeu Fabra

Centro de Estudios de Ciencia, Comunicación y Sociedad

Dr. Aiguader, 88. 08003 Barcelona, Spain

gema.revuelta@upf.edu

\begin{abstract}
This article analyses specialist journalists' perception of transformations in public communication on health and biomedicine in Spain over the last two decades. A total of 20 semi-structured interviews were carried out. The analysis uses the metaphorical concept of "ecosystem". According to the interviewees, the main "environmental" changes are technological (stressing the expansion and diversity of online information and the impact of social media). They perceive a multiplication and diversification among "information source-species". Among these, the visibility of specialist sources (researchers and healthcare professionals) and civil associations (patients and consumers) has increased, but "opportunistic species", such as promoters of fake news and pseudo-medicine, have also emerged. Health journalists rate their profession satisfactorily, while recognising that their working "environment" has deteriorated and perceiving a threat in the dependence on clickbait and social media positioning.
\end{abstract}

\section{Keywords}

Health communication; Health information; Biomedical communication; Specialized journalism; Journalists; Technological changes; Fake news; Information sources; Institutional communication; Social networks; Interviews.

\section{Introduction}

Almost two decades ago, Annette Flanagin, editor of the Journal of the American Medical Association (JAMA), predicted that

"the era of globalisation, with universal access to information thanks to the Internet and satellite broadcasts, would not lead to the disappearance of medical journalism; nor would it make medical journals or medical- and health-based news media obsolete" (Flanagin, 1999, p. 127).

In 2018 , this is indeed the case, yet the transformations that have taken place in the sector would have been hard to predict at the end of the last century. 


\section{Revolution, evolution and ecosystems}

In Flanagin's opinion, what was happening at that time was not a genuine revolution, but rather an evolution (Flanagin, 1999). The evolution-revolution dilemma also appears in other analyses on the magnitude of the transformation caused by information and communication technologies (ICT). By way of example, it is used to analyse the role of the Web 2.0 and social media (Coyle; Vaughn, 2008). Some studies do not explicitly refer to the term "revolution", but offer a radical interpretation of change, as in the following text:

It changes control over communication. In the traditional media and the Web 1.0, website owners have full control over the information published, access and desired level of interactivity. However, in the Web 2.0, control switches directly to all users under equal conditions. Control lies with the users of the social network (Cebrián-Herreros, 2008, p. 347).

How change is evaluated also depends on whether all processes and technologies are considered or just one aspect of them. For instance, León and García-Avilés argue that only the term evolution, and not revolution, can be used in the field of interactive TV, as the advances have not been as radical as originally thought (2008, p. 22). However, 10 years later, in relation to scientific communication in the digital media, the same author states,

"We live in a time of change -if not a change of time- where citizens are adopting a more active role in all areas of social action including science" (León; Bourk, 2018, p. 250).

The concept of evolution occasionally has connotations of the concept as used by biologists and ecologists to refer to the evolution of species and ecosystems. In fact, the word ecosystem, which comes from ecology, has also been used to describe the current communication environment, especially the digital environment (Bowman; Willis, 2005; Díaz-Nosty, 2013; Meso-Ayerdi et al., 2014; Rodríguez-Borges, 2014; Peñafiel, 2016).

\section{Mass media and the health communication ecosystem}

For better or worse, the media have steadily adapted to technological and social transformations over this period of time. A number of different stages have been identified in the field of health communication in Spain. Around the turn of the last century, there was an increase in specialist sections and the volume of information on the subject (Camacho-Markina, 2010, p. 145; Revuelta-De-la-Poza, 2006; 2012). However, with the crisis in journalism (exacerbated by the financial crisis and poor adaptation to new technologies), staff levels were cut, leading to the closure of many specialist sections, including health and/or science in some media outlets (Peñafiel-Saiz et al., 2014).

Cuesta-Cambra notes that advances in ICT have increased distribution of health information and facilitated communication between healthcare professionals and patients. However, according to the author, although users feel they can obtain up-to-date and reliable information on general health topics, there are real problems involved, such as the digital gap and the credibility and quality of information (Cuesta-Cambra, 2012). Concern for the quality of health information reaching the public is a constant theme in the literature, although it appears to have got worse in the last decade. Carmen Peñafiel et al. conclude that responsibility for the evolution of public information on health issues, including its quality, should be shared between physicians, journalists and, in general, all actors involved in such communication (Peñafiel-Saiz et al., 2014).

We are not aware of similar research in health journalism, but data from the Worlds of Journalism Study on Spain indicate that generally journalists are not just concerned about quality but also about the growing influence of social media, user-generated content (such as blogs) and audience feedback on their work.

http://www.worldsofjournalism.org

Most journalists interviewed in this study stated that audience intervention leads to pressure for greater sensationalism and making decisions based on constant audience research (Berganza; Herrero, 2016).
The media has changed, but so have the public and the role they now play

The media has changed, but so have the public and the role they now play. In the words of Carmen Peñafiel:

We have switched from communication 2.0 to communication 3.0, where praise is given to the socialisation of information by the public through the digital media, based on social criteria and a high degree of personalisation. The challenge for the media in the first quarter of the 21st century is to be where the people are and where they consume audiovisual content, with no limits in terms of geography and screens (Peñafiel-Sáiz, 2016).

Finally, the sources of information (physicians, researchers, government and industry representatives) have also undergone changes in the access, use and distribution of information. Scientists have direct access to the public, without going through the media (De-Semir; Revuelta-De-la-Poza, 2017, p. 126; León; Bourk, 2018, p. 251). With regard to sources (another sector that has changed in recent years yet is hardly studied), hospitals, research centres, universities and industry in the sector now have institutional press offices (García-Latorre; Aibar-Remón; Gobantes-Bilbao, 2017; Terrón-Blanco, 2018). 
In short, there have been many transformations in recent decades, in both general communication and specifically in health and biomedicine. Thus it is worth pausing to reflect on which transformations are most significant and what their implications are or may be in the future. An overview that also requires to considers the "time" (or fourth) dimension.

\section{Objective and frame of reference}

This article analyses specialist journalists' perception of transformations in public communication on health and biomedicine in Spain over the last two decades. Our frame of reference is the metaphorical construct "ecosystem" and its elements and attributes, as well as the processes that explain transformations within it and the impact on its evolution.

In the words of Ramón Margalef, one of the leading figures in ecology in Spain and internationally, ecosystems are:

"Systems formed by individuals of many species, within an environment of definable characteristics, and involved in a continual dynamic process of interaction, adjustment and regulation, expressed either as an exchange of matter and energy, or as a sequence of births and deaths, one of whose results is evolution of species and succession in terms of the whole system (Margalef, 1998, p. 2).

It is not hard to identify these elements in public communication on health and biomedicine:

- Individuals of many species. Metaphorically speaking, the species involved in public communication on health and biomedical issues consist of journalists (and other media professionals and directors), institutional communicators, healthcare professionals, researchers, industry representatives (pharmaceutical, food, well-being and cosmetics sectors), health administration representatives, general citizens and citizens organised into patients' or consumers' associations, among others.

- The environment. This refers to the set of spaces, channels and media inhabited by the different species and in which interactions occur between them. In health communication there is an online environment (social media, digital media, video platforms, search engines, websites, databases, repositories, etc.), an offline environment (communicators' workplace, the public space, printed newspapers, etc.) and even an intangible environment (work environment, environment related to the socioeconomic context, etc.).

- Interactions or relations between species, in which matter and energy (information, in our case) may be exchanged, can be diverse and occur at different levels, such as interactions between researchers-journalists, physicians-patients, media professionals-citizens, citizens-citizens, and so on.

Although we believe these elements can provide a better understanding of the subject of our study, as they relate this subject to a unit (the ecosystem) and explain changes in terms of modifications observed among its elements (species, environment and interactions), we stress that the use we make of them is solely metaphorical. Our study does not aim to fit the literal definition of ecosystem or the methods used in the study of ecology.

Finally, it is worth stressing that the aim of our study includes both health and biomedical communication. Health journalists generally cover aspects related to the health system and news on medicine and public health. If the media outlet also has a science journalist, he or she generally covers biomedical communication (molecular study of disease), as this is a research topic.

Thus, considering public communication on health and biomedicine in Spain as a (metaphorical) ecosystem, the specific research questions are:

Q1. What are the most significant environmental changes to occur in the last two decades?

Q2. What species cohabit in the current ecosystem and how do they differ from two decades ago?

Q3. What is the nature of interactions between species now and how do they differ from two decades ago?

\section{Methodology}

To answer these questions, we conducted 20 semi-structured interviews with specialist health and/or science journalists. We chose a qualitative methodology, as our intention is to explore the personal perceptions of these journalists, their experiences and their arguments regarding causes and consequences. The interviews and questions were based on recommendations by Ruiz-Olabuénaga (2012, pp. 165-190). The program Atlas.ti 8 Windows was used for recording, coding and analysis, and Coreq criteria were used to ensure quality when explaining the qualitative research (Tong; Sainsbury; Craig, 2007).

\subsection{Sample}

Intentional sampling was used to select the interviewees, i.e. we selected a sample of strategic subjects, based on their likely knowledge of the subject of study. We analysed 25 media websites, previously selected on the basis of their greater dissemination in their category (i.e. daily press, digital press, television, etc.) (AIMC, 2017; OJD Interactiva, 2017). Among these, we identified journalists who regularly cover health topics. We sent an invitation by email to a journalist from each media outlet and a further reminder a few weeks later by both email and phone. Given the poor response from journalists in the audiovisual media, we invited more journalists from print media (even repeating certain out- 
lets) and journalists freelancing for different media outlets. Our sample eventually consisted of 20 people (9 men and 11 women: 1 working in television, 3 freelancers with various media outlets, 5 working in native digital media and 11 in non-native digital newspapers). As the study covers a long period of time (two decades), fewer professionals were interviewed who had worked for the whole period $(n=8)$ compared to those who had only worked for part of it $(n=12)$. However, the latter's perception of what has happened over these years is considered valid for exploring the objectives of this study. Specifically, the sample consists of 2 journalists with over 30 years' experience, 6 with 20 to 30 years' experience, 6 with 10 to 19 years' experience and 6 with less than 10 years' experience. All were informed of the nature of the study and data processing policies and freely gave their consent.

\subsection{Interview script}

The specific script was as follows:

1) Tell us about your personal experience in the field of health (biomedical) information and your current professional situation;

2) In your opinion, what are the main changes in the field of health (biomedical) communication in the last two decades?;

3) How have you changed or how have changes affected you? (If no spontaneous answer given, ask about social media, formats, working conditions, content, social changes);

4) Based on your own experience, have sources of information changed in the field of health (biomedicine)? What about your relationship with them?;

5) Has the audience, and your interaction with it, changed?;

6) In general, is the work of health (biomedical) communicators better or worse than 20 years ago?;

7) Do you like your profession?;

8) Would you recommend it to a young person?

\subsection{Data collection and processing}

Between December 2017 and March 2018, 20 interviews were conducted by Skype or phone. The average length was 49 minutes. They were recorded and transcribed. The transcriptions were analysed using the qualitative research support program Atlas.ti 8 Windows. Coding the content began with an initial list of codes corresponding to the questions in the script. This list was gradually replaced by codes emerging from the data itself. The author analysed all the documents and identified quotes and codes. The final list contains 46 codes, only 5 of which were in the original list.

\subsection{Data analysis and interpretation}

The Atlas.ti 8 Windows program helped with obtaining a descriptive and quantitative overview of the data content. In addition, the frequency of code occurrence and co-occurrences between them contributed to the qualitative, interpretive data analysis. However, the number of times a code appears linked to the quotes from the interviews has a limited value for interpreting the content, while a single quote may be highly relevant in terms of meaning.

Thus, in the author's opinion, the main value of this program is that it permits the qualitative interpretive work to be systematised and guarantees its internal validity.

\section{Results}

\subsection{General quantitative description}

Graph 1 shows the frequency of occurrence of the 46 codes that emerged from studying the content of 20 interviews. The 10 most repeated codes are

- "Specialisation" ( $\mathrm{N}=189)$,

- "Working conditions" (N=151),

- "Quality" (N=137),

- "Content" (N=135),

- "Staff and professional teams" (N=129),

- "Audience" ( $\mathrm{N}=113)$,

- "Social media" (N=96),

- "Fake news and pseudo-medicine" (N=95),

- "Profession in general" $(\mathrm{N}=90)$, and

- "Economic conditions ( $\mathrm{N}=87$ ).

Co-occurrence or occurrence of several codes in the same quote is variable. For instance, the code "Main change" has its highest co-occurrence of 0.3 with the code "Internet in general". The code "Quality" has its highest co-occurrence (0.3) with "Content" and "Fake news and pseudo-medicine". 


\subsection{Qualitative description}

\subsubsection{Environmental changes}

In the interviewees' opinion, in the last two decades the main change in the environment of public communication on health and biomedicine has been technological, related to the spread of the Internet in general and digital transformations. Within this concept, opinions are equally divided between those who stress the almost complete access to all information (unanimously considered an advantage, for both journalists and the public) and those who focus on the role of social media and its impact. In the latter case, social media are considered reasonably beneficial for the public, as they are better connected and informed, but in general they tend to be seen as a threat to journalists' work, by having changed its distribution, giving greater visibility to more sensationalist, provocative and entertainment-based content.

I1: Well, the social media have their good side, because there is more general access to information. In other words, our news stories are probably more widely read. But the bad side is this: you don't know whether people really read them or just click on the headline and that's it, you know?

After technological changes, most of the interviewees mentioned changes in the environment where they work (generally changes common to the profession in general, but partly specific to the speciality). The most widely mentioned aspects are:

- "precarity" (relating to lower salaries, the firing of senior journalists and contracting younger ones with no experience or training);

- the work rate (demanding faster work and higher workload).

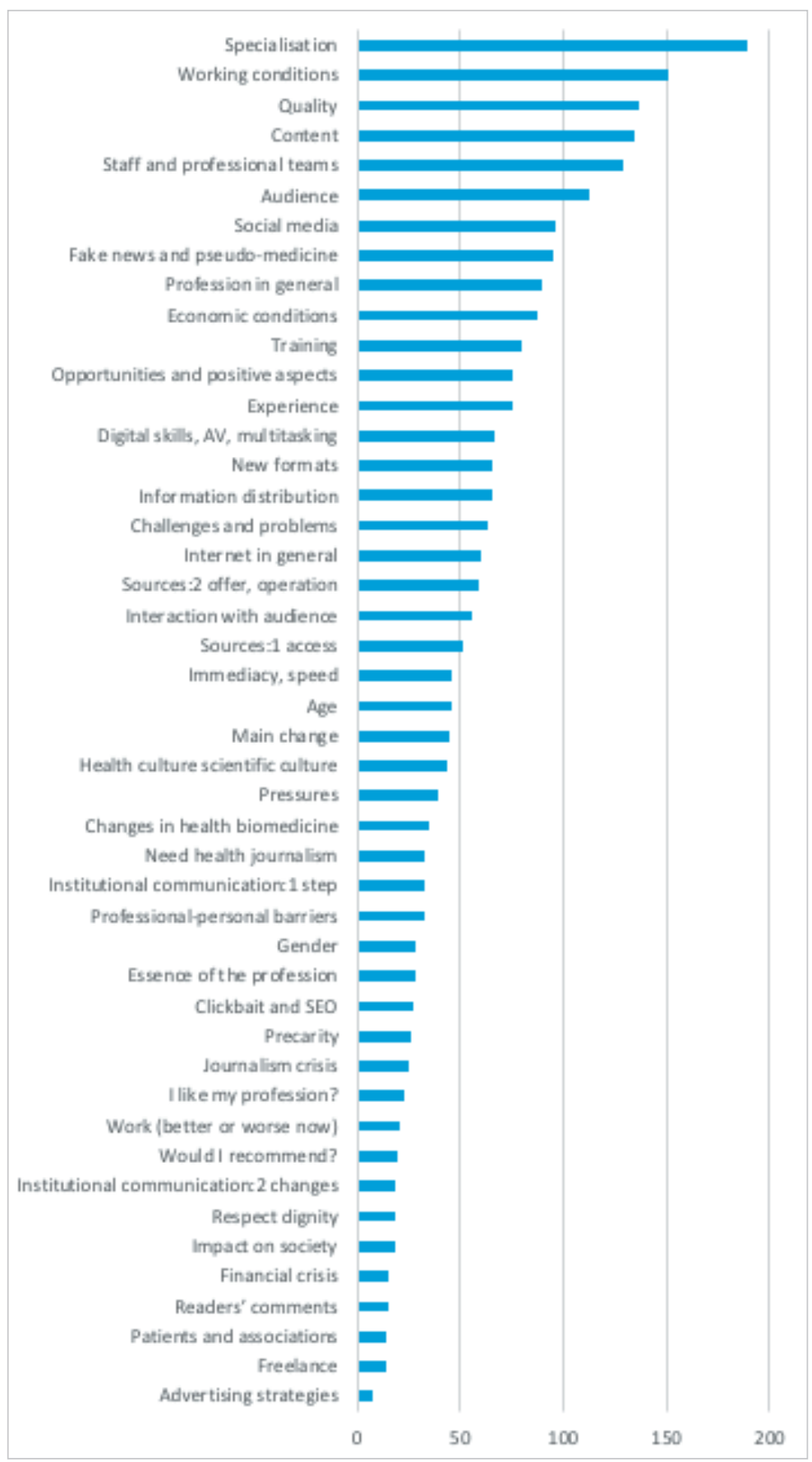

Graph 1. Frequency of code occurrence in the interviews

Currently, a single person can produce a greater volume of stories than a team of 4 to 5 people during the boom in health supplements.

14: However, in general, such immediacy and speed affect work times, and also affect the way users consume news.

113: Well, clearly you have less time and you have to deliver more stories; which means you have less time to work on them, less time to spend on them and possibly less time to go out and do interviews or check information. You make more use of press releases, more use of agency information, and this shows in...

\subsubsection{Changes among species cohabiting in the ecosystem}

Metaphorically speaking, the main change is that the "source of information" species has multiplied. First of all, sources that existed at the start of the century are now more visible and issue more information (e.g. health and science sector sources), while other non-expert sources have also sprung up and now play a bigger role.

The expert sources mentioned are hospitals, universities and scientific institutions, and whereas previously they would have found difficulty accessing the public (either directly or through the media), they have now learned to communicate and even employ professionals for the purpose. 
Among the species to have benefited from changes in the environment, mention is made of patients' and consumers' associations and a number of organised citizens' groups. Their presence has also increased, according to the journalists, not only for the same reason as with expert sources (they communicate more frequently and more professionally), but also because now health tends to be presented as storytelling.

A group of non-experts that deserves special attention, due to the importance attributed to them by the interviewees, are those that spread information and promote the use of pseudo-medicine (techniques, substances or products that, despite a lack of evidence on their efficacy, are presented as healthy and even curative). These are both citizens' groups and industry sources (or the part of it that leads the "alternative" label). These emerging pro-pseudo-medicine movements, together with promoters of fake news, require interviewees to be more alert, although they do not yet see them as a threat to themselves, as they specialise in health, but more so to non-specialist journalists and the public.

19: The problem is that we are now competing with what I said before: with various sources. So, obviously, before this, I was competing with newspaper $X$ and now I'm also competing with the blog of an Ayurveda Brahmin, who gives prescriptions on how to treat psoriasis.

110: There are people who demand information from white coats; there are people who demand information on what is happening at the cutting edge of the fight against cancer; and there are people who, increasingly, demand pseudo-medicines and lies and fake news.

The industry as a species intervenes as a source of both information and advertising, using highly diverse and complex tools. New forms for advertising (sponsored content, native advertising, etc.) interfere in the work of writing. The journalists interviewed see this change as a threat to the separation of information from advertising, although they themselves do not feel they have yet been affected by these pressures.

Medical professionals continue to play an important role in this ecosystem, generally because they, along with scientific journals and the health administration, are the main sources of information for health journalists.

The public (the main species in the ecosystem, according to the interviewees) has changed radically; in the interviewees' opinion they are not only the "audience" (i.e. passive receivers of information), but also use information in specific ways (the public searches for, clicks on, shares and rates it). There are an increasing number of non-expert groups that generate content and thus switch from being an audience-species to a source-species. Furthermore, the journalists think that the audience that consumes their health content is bigger today than at the start of the century, when it only reached people with a particular interest in such matters.

Some interviewees mention the transformation in the health culture and information-related behaviour of society as the main change over the past two decades. For some, society is now more familiar with technical issues (e.g. concepts such as genetic engineering) than two decades ago. They also mention that society today needs to be constantly and better informed. However, alongside this change, there is also the perception of a trend towards consuming superficial, anecdotal or merely entertaining content, rather than proper information.

14: I think that people are more aware of their health, the importance of good quality of life and so on; and this is why the information that gets published should be accurate.

15: So far, society's general knowledge on health issues has improved a little. Previously, journalists were trying to explain things the public didn't know. This has now changed a little. We are now better informed.

I1: Right now, when you see what people click on, and what they click on most is rubbish, you think, "It's going to get ridiculous, if this is what they want!"

As mentioned in this and the previous section, specialist journalists' opinion of themselves as a species is that they are threatened by a heavier workload and worse working conditions, but nevertheless they do not feel worse off compared to other areas of journalism (some interviewees even described health journalists as privileged). Indeed, all the interviewees feel satisfied with their profession and consider that specialist health journalism not only remains necessary, but is also more so than ever.

I13: I think that it is better in terms of possibilities for professional progress, and professional development. It is worse in financial terms for some. But it is better in terms of professional development. It has become a more important area of information than 20 years ago, without a doubt.

I10: I was thinking in comparison to other branches of journalism. For instance, this branch of journalism is, overall, highly recommendable. It tends to be less stressful. Everything I said about having to do hundreds of things and so on, in our field (in general) is more manageable than in other areas, because you could say there are fewer surprises, you see? There might be a case of Ebola, a case of whatever, but such things are rare. And you get the chance to do things that are really satisfying.

Particular mention is made of demands for skills that were not previously required. This can be summarised by the terms "multiskilled" and "multitasking". In some media outlets, journalists are asked to handle multiple formats (especially digital and audiovisual skills) and they know the intricacies of search-engine optimisation. These demands, combined 
with specialist skills (knowledge in the fields of health, medicine, biomedical research, etc.) are difficult to combine in a single person. Journalists are divided between those who see this as an opportunity and, more frequently, those who see it as a threat.

I16: Video is becoming increasingly important. So there are journalists who learn to use basic video editing tools and are capable of editing a five-minute, two-minute or one-minute report, explaining a new story, right? Well, this is a future change, isn't it?

According to the interviewees, the only profile that seems to be disappearing (if it has not done so already) is that of senior journalists who, at the start of the century, had time to work on topics and concern themselves only with their articles for the newspaper or supplements. .

\subsubsection{Interactions between species}

Interactions are more numerous among all species and are much more complex.

Relations between journalists and sources have changed, according to the interviewees, mainly because now there are many more, who send more information and who are better at doing so. Professionalisation of institutional communication in the health and science world is mentioned by several interviewees. The information is presented more attractively and is designed with journalists in mind.

16: In addition, the appearance of institutions and organisations that have professional journalists working for them, helping them write news stories and then disseminating them among journalists, also increases the pressure on journalists from pre-prepared news stories.

With regard to the audience, the journalists interviewed are divided in their experiences. One group describe having fluid contact with the audience, especially via Twitter. The other group do not feel they interact more with their audience than they did 20 years ago, although they recognise that their editorial boards include people responsible for social media and interaction. Whether or not they interact with the audience over social media (or comments sections), interviewees mention the pressure they receive indirectly from the audience, as their habits, clicks and ratings mark the success of articles. Given this situation, some journalists recognise they have learned to add more attractive headlines and write with social media in mind. Others, however, say they still do their work without taking this type of pressure into consideration.

117: Well, in fact, it doesn't have much effect. [...] Now, they'll let you know on Twitter, which might be faster. I don't know, but I think the bar has always been set high. We haven't dropped our guard at any time.

I1: And if they're going to click on your story you have to have a good, striking headline.

\section{Discussion and conclusions}

The main contribution of applying the ecological ecosystem metaphor to the analysis of transformations in public communication on health and biomedicine in Spain in the last two decades is to group all elements involved in this communication in a single, familiar unit. This makes it easier to identify changes and their dimensions, and analyse their consequences. The three elements into which the analysis is divided (environment, species and interactions between species) are experiencing transformations that have consequences for each other and for the ecosystem as a whole.

Applying the perspective of time helps provide a more accurate assessment of the effect of both major disruptions, which have ostensibly modified the system, and small disruptions that act continually over time and which can also modify the environment or cohabitation among species. In ecology, a major disruption that radically changes the system might be a hurricane or a fire, while a small but continual disruption, which also modifies the system, would be something like "the simple and constant trampling of hares on pastureland" (Meling-López, 2008, p. 44).

In public health communication, the most visible disruption over these years has been the appearance and expansion of social media, together with new commercial strategies. These strategies, based on commercial algorithms, have changed the control of information distribution. If in the ecosystem two decades ago this control was mainly exercised by the print media, today control on the distribution of information (and other content) is mainly exercised by the social media; in other words, the companies that own social networks and the companies that advertise on them.

A less obvious, but continual, change or disruption is the steady entry of information on the Internet from increasingly diverse and numerous sources (including expert and non-expert sources, sources with commercial or non-commercial interests and declared or undeclared interests, among others). Both disruptions, along with other technological changes, have substantially modified the environment in which health communication takes place.
In public health communication, the most visible disruption over these years has been the appearance and expansion of social media, together with new commercial strategies 
In journalists' professional environment there are also very obvious disruptions, such as changes in working conditions and salaries, associated with the general crisis in journalism and the financial crisis. These have had a major impact on the health journalist "species", without having posed a big enough threat to create dissatisfaction with the profession, or feel they no longer have a socially relevant mission. Other disruptions are not so apparent but have profoundly modified the working environment. These include editorial decisions increasingly based on immediate audience response (clickbait) and social media positioning, and the pressure from new forms of advertising on the work of providing information (or editing).

The species that cohabit in this ecosystem are essentially the same (the public, journalists, sources of information), but there are changes in each of these groups. The species "sources" has multiplied and diversified. Expert sources (medical professionals, researchers, academia) that already existed at the start of the century are now more visible and have greater contact with other species. They have also professionalised their communication. In addition, changes in environmental conditions have facilitated the proliferation of sources that in the original ecosystem were largely unseen (acting as "opportunistic" species). Such emerging sources include civil associations (mainly patients and consumers), non-expert sources that produce all kinds of health information and sources that specifically spread false or baseless information (such as pseudo-medicine).

The visibility of patients' and consumers' associations as sources of information is, according to the interviewees, related to greater professionalism in these groups' communication and also due to a trend towards storytelling, for which patient testimonies are a perfect fit.

The emergence of sources of fake news and pseudo-medicine, together with the change in the distribution of journalism, geared towards clickbait and greater social media impact, is already having an effect on the content most visible to the public. Concern over the effect of communication in muddying societies is not new (Ursell, 2001), but in the case of health and especially the current ecosystem, the issue has gained greater importance.

Responsibility for the future evolution of this ecosystem is in the hands of the sources (healthcare professionals, researchers, the government, industry, civil associations and citizens who create content) and journalists, but especially in the hands of traditional and social media managers. And, finally, it is also in the hands of the public and their behaviour in relation to information.

\section{Referencess}

AIMC (2017). Resumen general del EGM, febrero a noviembre de 2017. Madrid: Asociación para la Investigación de Medios de Comunicación.

Berganza, Rosa; Herrero-Jiménez, Beatriz (2016). Journalists in Spain. Worlds of journalism study. Madrid. https://epub.ub.uni-muenchen.de/30117/1/Country_report_Spain.pdf

Bowman, Shayne; Willis, Chris (2005). "The future is here, but do news media companies see it?". Nieman reports, v. 59, n. 4, pp. 6-10.

https://niemanreports.org/articles/the-future-is-here-but-do-news-media-companies-see-it

Camacho-Markina, Idoia (2010). La especialización en periodismo. Zamora: Comunicación Social Ediciones y Publicaciones. ISBN: 9788492860272

Cebrián-Herreros, Mariano (2008). “La web 2.0 como red social de comunicación e información”. Estudios sobre el mensaje periodístico, n. 14, pp. 345-361.

http://revistas.ucm.es/index.php/ESMP/article/view/12775

Coyle, Cheryl L.; Vaughn, Heather (2008). “Social networking: Communication revolution or evolution?”. Bell Labs technical journal, v. 13, n. 2, pp. 13-17.

https://doi.org/10.1002/bltj.20298

Cuesta-Cambra, Ubaldo (2012). "Las TICs y la salud desde una perspectiva psicosocial”. Revista de comunicación y salud, v. 2, n. 1, pp. 29-33.

https://dialnet.unirioja.es/servlet/articulo?codigo=3818637

De-Semir, Vladimir; Revuelta-De-la-Poza, Gemma (2017). Periodistas científicos: corresponsales en el mundo de la investigación y el conocimiento. Barcelona: UOC. ISBN: 9788491167853

Díaz-Nosty, Bernardo (2013). La prensa en el nuevo ecosistema informativo. iQue paren las rotativas! Barcelona: Ariel; Fundación Telefónica. ISBN: 9788408112969

http://boletines.prisadigital.com/la_prensa_en_el_nuevo_ecosistema_informativo.pdf

Flanagin, Annette (1999). "La globalización de la información sobre medicina y salud”. Quark. Ciencia, medicina, comunicación y cultura, n. 16, pp. 2-4.

https://www.raco.cat/index.php/Quark/article/view/54784 
García-Latorre, Florencio-Jesús; Aibar-Remón, Carlos; Gobantes-Bilbao, Maite (2017). “La comunicación institucional de contenidos sanitarios mediante notas de prensa y su reflejo en la prensa diaria. El caso de Aragón". Revista española de comunicación en salud, v. 8, n. 1, pp. 38-53.

https://e-revistas.uc3m.es/index.php/RECS/article/view/3605

León, Bienvenido; Bourk, Michael J. (2018). Communicating science and technology through online video: Researching a new media phenomenon. New York: Routledge. ISBN: 9781351054584

León, Bienvenido; García-Avilés, José-Alberto (2008). "La visión de los productores sobre la televisión interactiva: el final de la utopía". Comunicación y sociedad, v. 21, n. 1, pp. 7-24.

https://www.unav.es/fcom/communication-society/es/articulo.php?art_id=41

Margalef, Ramón (1998). Ecología. 9a ed. Barcelona: Ediciones Omega. ISBN: 9788428204057

Meling-López, Alf-Enrique (2008). “La ecología en la cuarta dimensión”. Revista Universidad de Sonora, n. 23, pp. 44-46. http://www.revistauniversidad.uson.mx/revistas/23-9La\%20ecolog\%EDa\%20en\%20la\%20cuarta\%20dimension.pdf

Meso-Ayerdi, Koldobika; Larrondo-Ureta, Ainara; Peña-Fernández, Simón; Rivero-Santamarina, Diana (2014). “Audiencias activas en el ecosistema móvil. Análisis de las opciones de interacción de los usuarios en los cibermedios españoles a través de la web, los teléfonos móviles y las tabletas". Hipertext.net, n. 12.

https://doi.org/10.2436/20.8050.01.9

OJD Interactiva (2017). Medios digitales OJD interactiva. Auditoría medios online noviembre 2017.

https://www.ojdinteractiva.es/medios-digitales\#

Peñafiel-Sáiz, Carmen (2016). "Reinvención del periodismo en el ecosistema digital y narrativas transmedia”. adComunica, n. 12, pp. 163-182.

https://doi.org/10.6035/2174-0992.2016.12.10

Peñafiel-Sáiz, Carmen; Camacho-Markina Idoia; Aiestaran-Yarza, Alazne; Ronco-López, Milagros; Echegaray-Eizaguirre, Lázar (2014). "La divulgación de la información de salud: un reto entre sectores implicados". Revista latina de comunicación social, n. 69, pp. 135-151.

https://doi.org/10.4185/RLCS-2014-1005

Revuelta-De-la-Poza, Gema (2006). "Salud y medios de comunicación en España”. Gaceta sanitaria, v. 20, suppl. 1, pp. 203-208.

https://doi.org/10.1157/13086045

Revuelta-De-la-Poza, Gema (2012). “Salud en España durante el período 2000-2009: aproximación a través del análisis de la prensa". Medicina clínica, v. 138, n. 14, pp. 622-626.

https://doi.org/10.1016/j.medcli.2011.03.011

Rodríguez-Borges, Rodrigo-Fidel (2014). “¿Crisis del periodismo y crisis de la democracia? Una reconsideración del oficio periodístico en el ecosistema digital". Dilemata, n. 14, pp. 1-17.

https://www.dilemata.net/revista/index.php/dilemata/article/view/261

Ruiz-Olabuénaga, José-Ignacio (2012). Metodología de la investigación cualitativa. $5^{\text {a }}$ ed. Bilbao: Universidad de Deusto. ISBN: 9788474854237

Terrón-Blanco, José-Luis (2018). “Una aproximación a la información sobre salud en los medios de comunicación”. Portal de la comunicación. Lecciones.

http://www.portalcomunicacion.com/lecciones_det.asp?id=100

Tong, Allison; Sainsbury, Peter; Craig, Jonathan (2007). “Consolidated criteria for reporting qualitative research (Coreq): a 32-item checklist for interviews and focus groups". International journal for quality in health care, v. 19, n. 6, pp. $349-357$. https://doi.org/10.1093/intqhc/mzm042

Ursell, Gillian D. M. (2001). “Dumbing down or shaping up?”. Journalismo, v. 2, n. 2, pp. 175-196.

https://doi.org/10.1177/146488490100200204

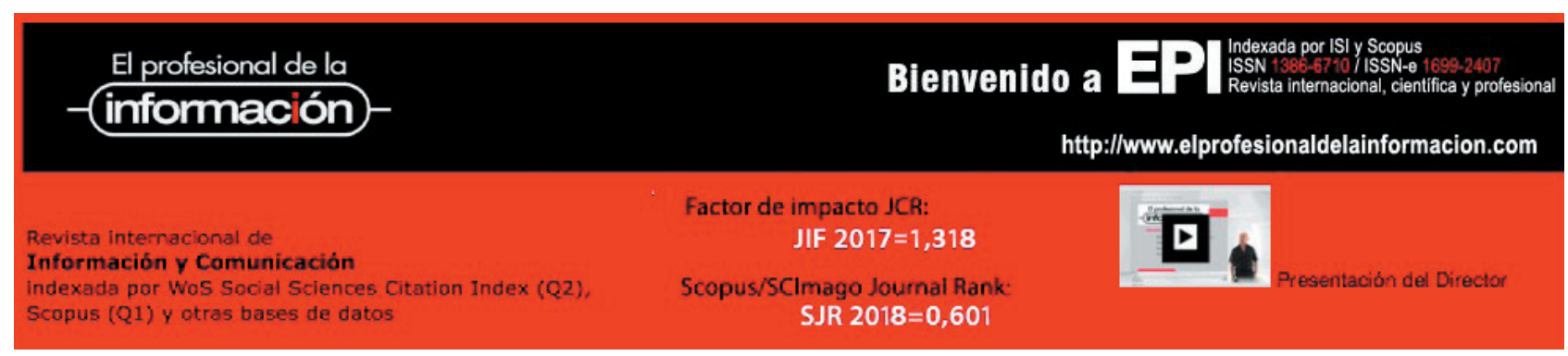

